\title{
Iron-glutamate-silicotungstate ternary complex as highly active heterogeneous Fenton-like catalyst for 4-chlorophenol degradation
}

\author{
Dongju Yin, Lizhong Zhang, Xiufeng Zhao*, Han Chen, Qian Zhai \\ Department of Chemistry and Applied Chemistry, Changji University, Changji 831100, Xinjiang, China
}

\section{A R T I C L E I N F O}

Article history:

Received 30 August 2015

Accepted 7 November 2015

Published 20 December 2015

\section{Keywords:}

Polyoxometalate

Silicotungstate

Heterogeneous catalysis

Fenton oxidation

4-Chlorophenol degradation

\begin{abstract}
A B S T R A C T
A novel iron-glutamate-silicotungstate ternary complex ( $\left.\mathrm{Fe}^{\varpi} \mathrm{GluSiW}\right)$ was synthesized from ferric chloride ( $\mathrm{Fe}^{\mathrm{III}}$ ), glutamic acid (Glu), and silicotungstic acid (SiW), and used as a heterogeneous Fenton-like catalyst for 4-chlorophenol (4-CP) degradation at neutral $\mathrm{pH}$ value. The prepared Fe ${ }^{\varpi G l u S i W}$ was characterized using inductively coupled plasma atomic emission spectroscopy, thermogravimetry, Fourier-transform infrared spectroscopy, ultraviolet-visible diffuse reflectance spectroscopy, X-ray diffraction, and field-emission scanning electron microscopy. The results showed that $\mathrm{Fe}{ }^{\varpi} \mathrm{GluSiW}$ has the formula $\left[\mathrm{Fe}\left(\mathrm{C}_{5} \mathrm{H}_{8} \mathrm{NO}_{4}\right)\left(\mathrm{H}_{2} \mathrm{O}\right)\right]_{2} \mathrm{SiW}_{12} \mathrm{O}_{40} \cdot 13 \mathrm{H}_{2} \mathrm{O}$, with glutamate moiety and Keggin-structured $\mathrm{SiW}_{12} \mathrm{O}_{40}{ }^{4-}$ heteropolyanion. The catalyst showed high catalytic activity in 4-CP degradation in the dark and under irradiation. Under the conditions of 4-CP $100 \mathrm{mg} / \mathrm{L}$, $\mathrm{Fe}{ }^{\varpi} \mathrm{GluSiW} 1.0 \mathrm{~g} / \mathrm{L}, \mathrm{H}_{2} \mathrm{O}_{2} 20 \mathrm{mmol} / \mathrm{L}$, and $\mathrm{pH}=6.5$, 4-CP was completely decomposed in $40 \mathrm{~min}$ in the dark and in $15 \mathrm{~min}$ under irradiation. When the reaction time was prolonged to $2 \mathrm{~h}$, the corresponding total organic carbon removals under dark and irradiated conditions were ca. $27 \%$ and $72 \%$, respectively. The high catalytic activity of FellI GluSiW is resulted from hydrogen bonding of $\mathrm{H}_{2} \mathrm{O}_{2}$ on the $\mathrm{Fe}^{\mathrm{III}} \mathrm{GluSiW}$ surface. The enhanced degradation of 4-CP under irradiation arises from simultaneous oxidation of 4-CP through Fenton-like and photocatalytic processes respectively catalyzed by ferric iron and the $\mathrm{SiW}_{12} \mathrm{O}_{40} 0^{4-}$ hetropolyanion in $\mathrm{Fe}^{\varpi} \mathrm{GluSiW}$.
\end{abstract}

(C) 2015, Dalian Institute of Chemical Physics, Chinese Academy of Sciences. Published by Elsevier B.V. All rights reserved.

\section{Introduction}

The pollution of water resources has become a serious problem and is causing public concern. Chlorophenols (CPs) are one of various organic contaminants in the environment. These toxic compounds are widespread and suspected carcinogens [1]. CPs have been widely used as raw materials and synthetic intermediates in many industrial processes. Because of their broad-spectrum antimicrobial properties, CPs have also been widely used as preservatives and disinfectants. CPs are generated as side products in the disinfection of drinking water and bleaching of pulp with chlorine as well. CPs are resistant to biodegradation; therefore, discharge of large amounts of these compounds into the environment is a threat to human health and ecosystems [2].

The Fenton process is an effective method for degrading a wide range of organic pollutants in water. The Fenton reaction is based on the catalytic decomposition of $\mathrm{H}_{2} \mathrm{O}_{2}$ by $\mathrm{Fe}^{2+}$ ions in aqueous solution to produce $\mathrm{HO}$, which can non-selectively oxidize most organic compounds. Catalysis by $\mathrm{Fe}^{2+}$ ions involves the $\mathrm{Fe}^{2+} \leftrightarrows \mathrm{Fe}^{3+}$ redox cycle shown in Eqs. (1) and (2) [3]:

$$
\begin{aligned}
& \mathrm{Fe}^{2+}+\mathrm{H}_{2} \mathrm{O}_{2} \rightarrow \mathrm{Fe}^{3+}+\mathrm{HO}^{-}+\mathrm{HO} \\
& \mathrm{Fe}^{3+}+\mathrm{H}_{2} \mathrm{O}_{2} \rightarrow \mathrm{Fe}^{2+}+\mathrm{H}^{+}+\mathrm{HO}_{2}
\end{aligned}
$$

However, because the reduction of $\mathrm{Fe}^{3+}$ to $\mathrm{Fe}^{2+}$ via Eq. (2) is

\footnotetext{
*Corresponding author. Tel/Fax: +86-994-2352065; E-mail: zhaoxiufeng19670@126.com This work was supported by the National Natural Science Foundation of China (51268001). 
much slower than the oxidation of $\mathrm{Fe}^{2+}$ to $\mathrm{Fe}^{3+}$ via Eq. (1), the traditional homogeneous Fenton process needs a high concentration of ferrous salt (50-80 mg/L). The subsequent treatment of iron-containing water and ferric hydroxide sludge therefore consumes large amounts of chemicals. Additionally, the homogeneous Fenton process typically works under acidic conditions $(\mathrm{pH}=2.0-3.0)$, which is unfavorable in practice because of the costs of acidification during processing and neutralization after treatment [4-6]. To overcome these disadvantages of the homogeneous Fenton process, and to achieve catalyst recycling, much effort has been made to develop heterogeneous Fenton-like catalysts [7-12]. However, many of the heterogeneous Fenton-like catalysts reported in the literature still require acidic $\mathrm{pH}$ conditions, and some of them show significant deactivation in consecutive reaction cycles [13-17]. The development of reusable and efficient heterogeneous Fenton-like catalysts with wide working $\mathrm{pH}$ ranges is therefore highly desirable.

Polyoxometalates (POMs), which are multi-metal oxygen clusters, have been intensively studied as catalysts because of their ability to undergo multi-electron transfer reversibly. Irradiation with light of energy higher than or equal to that of the highest occupied molecular orbital-lowest unoccupied molecular orbital (HOMO-LUMO) gap of a POM results in charge transfer from $\mathrm{O}^{2-}$ to $\mathrm{M}^{6+}(\mathrm{M}=\mathrm{W}, \mathrm{Mo})$ at $\mathrm{M}-\mathrm{O}-\mathrm{M}$ bonds, leading to the formation of an excited POM with strong oxidizing power [18-22]. Recently, the use of POMs in Fenton or related processes has been attracting increasing attention. Choi's group [23] reported that $\mathrm{SiW}_{12} \mathrm{O}_{40} 0^{4-}$ or $\mathrm{PW}_{12} \mathrm{O}_{40^{3-}}$ in the $\mathrm{Fe}^{0} / \mathrm{O}_{2}$ system can mediate electron transfer from $\mathrm{Fe}^{0}$ to $\mathrm{O}_{2}$ to produce $\mathrm{Fe}^{2+}$ and $\mathrm{H}_{2} \mathrm{O}_{2}$. Sedlak's group [24] showed that addition of $\mathrm{PW}_{12} \mathrm{O}_{40}{ }^{3-}$ to the $\mathrm{Fe}^{3+} / \mathrm{H}_{2} \mathrm{O}_{2}$ homogeneous system extends the working $\mathrm{pH}$ range up to $\mathrm{pH}=8.5$. Taghdiri et al. [25] reported that silicotungstic acid catalyzes the oxidation of hexamethylenetetramine in the presence of $\mathrm{H}_{2} \mathrm{O}_{2}$ or $\mathrm{H}_{2} \mathrm{O}_{2} / \mathrm{Fe}^{2+}$. These studies suggest potential synergies between iron and POM for catalytic oxidation of pollutants by $\mathrm{H}_{2} \mathrm{O}_{2}$. It is therefore reasonable to infer that water-insoluble complexes containing both iron and heteropolyanions would be efficient heterogeneous Fenton-like catalysts. However, binary complexes of iron ions $\left(\mathrm{Fe}^{2+}\right.$ or $\left.\mathrm{Fe}^{3+}\right)$ with many heteropolyanions (e.g., $\mathrm{SiW}_{12} \mathrm{O}_{40}{ }^{4-}$ and $\mathrm{PW}_{12} \mathrm{O}_{40} 0^{3-}$ ) are soluble in water [24].

Recently, we found that some amino acids can link $\mathrm{Fe}^{3+}$ ions with various heteropolyanions in aqueous solution to form water-insoluble ternary complexes; these complexes show Fenton-like catalytic activity [26,27]. Here, we report a new

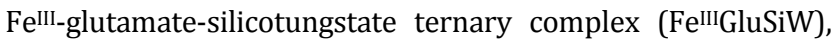
which acts as a highly active heterogeneous Fenton-like catalyst in the degradation of 4-chlorophenol (4-CP) at neutral $\mathrm{pH}$

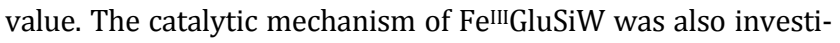
gated.

\section{Experimental}

\subsection{Reagents}

Ferric chloride hexahydrate, glutamic acid, silicotungstic acid, sodium silicate, sodium tungstate, and $\mathrm{H}_{2} \mathrm{O}_{2}$ (30\%) were provided by the Sinopharm Chemical Reagent Beijing Co., Ltd. 4-CP was purchased from the Tianjin Guangfu Fine Chemical Industry Research Institute. All reagents were analytical grade and used without further purification.

\subsection{Preparation and characterization of $\mathrm{Fe}^{\amalg} \mathrm{GluSiW}$}

FeШGluSiW was synthesized by precipitation in aqueous solution at ambient temperature. Ferric chloride hexahydrate $(0.27 \mathrm{~g})$ and glutamic acid $(0.15 \mathrm{~g})$ were dissolved in water (25 $\mathrm{mL}$ ) to form a red soluble complex of $\mathrm{Fe}^{3+}$ ions and glutamate. A solution of silicotungstic acid (25 mL, $0.02 \mathrm{~mol} / \mathrm{L})$ was added dropwise, precipitating Fe山GluSiW. The precipitate was aged for $24 \mathrm{~h}$ at room temperature, and red-brown Fe ${ }^{\amalg G l u S i W}$ powder was obtained by washing the precipitate with water and drying at $50{ }^{\circ} \mathrm{C}$ under vacuum.

The prepared FeIIIGluSiW was characterized using inductively coupled plasma atomic emission spectroscopy (ICP-AES; Shimadzu ICPS-7510), thermogravimetry (TG; Seiko TG/DTA6300), Fourier-transform infrared (FT-IR) spectroscopy (Shimadzu IRAffinity-1), ultraviolet-visible diffuse reflectance spectroscopy (UV-Vis DRS; Shimadzu UV2550), X-ray diffraction (XRD; XD-2, Cu $K_{\alpha}$ radiation), and field-emission scanning electron microscopy (FE-SEM; Hitachi S-4800).

\subsection{4-CP degradation}

Degradation of 4 -CP was performed at $25 \pm 2{ }^{\circ} \mathrm{C}$ in an Fe'IIGluSiW $/ \mathrm{H}_{2} \mathrm{O}_{2}$ system under both dark and irradiated conditions. All experiments were performed in a cylindrical quartz tube under magnetic stirring. A $400 \mathrm{~W}$ high-pressure mercury lamp was used as the irradiation source; it was surrounded by a quartz jacket to enable water cooling. A cutoff filter was placed around the lamp to remove radiation below $350 \mathrm{~nm}$. In a typical procedure, FeIIIGluSiW powder was added to 4-CP solution $(100 \mathrm{mg} / \mathrm{L})$ with stirring to maintain a uniform suspension. The suspension $\mathrm{pH}$ was adjusted using dilute $\mathrm{H}_{2} \mathrm{SO}_{4}$ or $\mathrm{NaOH}$ solution, and then $\mathrm{H}_{2} \mathrm{O}_{2}$ was added. No $\mathrm{pH}$ control was applied during the process. In the photo-assisted Fenton-like process, $\mathrm{H}_{2} \mathrm{O}_{2}$ addition and irradiation of the reaction system were performed simultaneously. Specimens were withdrawn at regular time intervals and analyzed immediately after filtration through a $0.22 \mu \mathrm{m}$ filter to remove the Fe ${ }^{\mathrm{III}} \mathrm{GluSiW}$ powder. Experiments were performed in triplicate, and all the results were expressed as mean values.

The 4-CP concentration was determined using a high-performance liquid chromatography (HPLC) system (Shimadzu LC-20AD) equipped with C18 reverse-phase column and UV detector. The mobile phase was a mixture of methanol (65\%) and $1 \%$ acetic acid aqueous solution (35\%) at a flow rate of 0.5 $\mathrm{mL} / \mathrm{min}$. The total organic carbon (TOC) content was determined using a TOC analyzer (Shimadzu TOC-V CPH).

\section{Results and discussion}

\subsection{Fe ${ }^{W}$ GluSiW characterization}




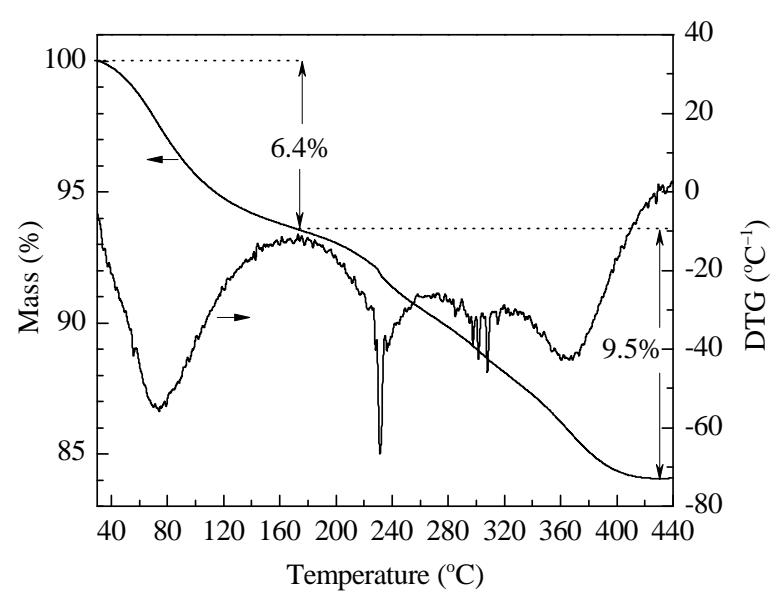

Fig. 1. TG and DTG curves of $\mathrm{Fe}^{\varpi} \mathrm{GluSiW}$.

The ICP-AES, TG, and FT-IR results show that the chemical formula of $\mathrm{Fe}{ }^{\mathrm{G}} \mathrm{GluSiW}$ is $\left[\mathrm{Fe}\left(\mathrm{C}_{5} \mathrm{H}_{8} \mathrm{NO}_{4}\right)\left(\mathrm{H}_{2} \mathrm{O}\right)\right]_{2} \mathrm{SiW}_{12} \mathrm{O}_{40} \cdot 13 \mathrm{H}_{2} \mathrm{O}$. The ICP-AES data for the $\mathrm{Fe}, \mathrm{Si}$, and $\mathrm{W}$ contents in $\mathrm{Fe}{ }^{ш \mathrm{GluSiW}}$ are close to the values calculated based on the suggested chemical formula. Calcd for Fe ${ }^{\mathrm{III}} \mathrm{GluSiW}(\%)$ : Fe 3.15, Si 0.79, W 62.2; found (\%): Fe 3.62, Si 0.75, W 61.1.

The TG curve of FelliGluSiW in Fig. 1 shows a multi-step mass loss in the range $30-425^{\circ} \mathrm{C}$. The $6.4 \%$ mass loss in the first step, from 30 to $174{ }^{\circ} \mathrm{C}$, arises from loss of the 13 crystallization water molecules (anal., calcd: 6.6\%). The 9.5\% mass loss in the subsequent steps, from 174 to $425^{\circ} \mathrm{C}$, is caused by loss of the coordinated water molecule and stepwise destruction of the glutamate moiety (anal., calcd: 9.3\%). The TG data are in agreement with the proposed chemical formula.

The FT-IR spectrum of a POM reflects the structure of the heteropolyanion, i.e., the primary structure. The FT-IR spectrum of Fe ${ }^{Ш G l u S i W}$ is shown in Fig. 2(1) and the assignments of the main absorption peaks, based on literature values $[28,29]$, are listed in Table 1. The FT-IR spectrum of FeШGluSiW has the characteristic peaks of Keggin-structured $\mathrm{SiW}_{12} \mathrm{O}_{40} 0^{--}$at 986, 920,881 , and $793 \mathrm{~cm}^{-1}$; these are respectively attributed to the stretching vibrations of terminal $\mathrm{W}=\mathrm{O}$ bonds, tetrahedral $\mathrm{Si}-\mathrm{O}$ bonds, and two types of bridging $\mathrm{W}-\mathrm{O}-\mathrm{W}$ bonds in $\mathrm{SiW}_{12} \mathrm{O}_{40}{ }^{4-}$.

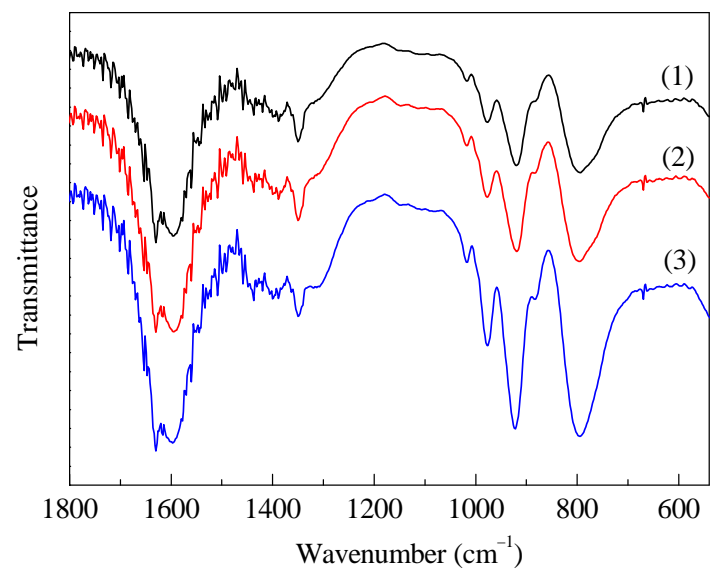

Fig. 2. FT-IR spectra of (1) $\mathrm{Fe}^{\varpi} \mathrm{GluSiW},(2) \mathrm{Fe}{ }^{\varpi} \mathrm{GluSiW}$ used under irradiation, and (3) $\mathrm{Fe}^{\varpi G} \mathrm{GluSiW}$ used in the dark.
Table 1

Main relevant FT-IR data (in $\mathrm{cm}^{-1}$ ) of Fe ${ }^{\mathrm{III}} \mathrm{GluSiW}$ and their assignments.

\begin{tabular}{|c|c|c|c|}
\hline $\mathrm{Fe}^{\mathrm{III}} \mathrm{GluSiW}$ & 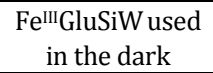 & $\begin{array}{l}\text { Fe }{ }^{I I I} \text { GluSiW used } \\
\text { under irradiation }\end{array}$ & Assignment \\
\hline 793 & 795 & 797 & $v_{\mathrm{a}}(\mathrm{W}-\mathrm{O}-\mathrm{W})$ \\
\hline 881 & 883 & 883 & $v_{\mathrm{a}}(\mathrm{W}-\mathrm{O}-\mathrm{W})$ \\
\hline 920 & 918 & 920 & $v_{\mathrm{a}}(\mathrm{Si}-0)$ \\
\hline 986 & 986 & 986 & $v_{\mathrm{a}}(\mathrm{W}=0)$ \\
\hline 1349 (m) & 1349 (m) & 1349 (m) & $\delta(\mathrm{CH})$ \\
\hline $1437(w)$ & $1438(w)$ & $1437(w)$ & $\delta\left(\mathrm{CH}_{2}\right)$ \\
\hline $1459(w)$ & $1459(w)$ & $1459(w)$ & $\delta\left(\mathrm{CH}_{2}\right)$ \\
\hline $1507(w)$ & $1507(w)$ & $1507(w)$ & $\delta\left(\mathrm{NH}_{3}{ }^{+}\right)$ \\
\hline $1617(\mathrm{sh})$ & $1617(\mathrm{sh})$ & $1617(\mathrm{sh})$ & $v_{\mathrm{a}}\left(\mathrm{CO}_{2}^{-}\right)$ \\
\hline 1630 (vs) & 1630 (vs) & 1630 (vs) & $v_{\mathrm{a}}\left(\mathrm{CO}_{2}^{-}\right)$ \\
\hline
\end{tabular}

m: medium, w: weak, sh: shoulder, vs: very strong.

Structural information on the glutamate moiety can also be obtained from the FT-IR spectrum. The peaks at 1630 and 1617 $\mathrm{cm}^{-1}$ correspond to the asymmetric vibrations of two $\mathrm{COO}^{-}$ groups of glutamate. The absorption at $1507 \mathrm{~cm}^{-1}$ is assigned to the bending vibration of $\mathrm{NH}_{3}{ }^{+}$. The $\mathrm{CH}_{2}$ and $\mathrm{CH}$ bending modes are observed at 1459, 1437, and $1349 \mathrm{~cm}^{-1}$. The FT-IR data verify the presence of Keggin-structured $\mathrm{SiW}_{12} \mathrm{O}_{40^{4-}}$ and glutamate moiety in $\mathrm{Fe}^{\varpi} \mathrm{GluSiW}$.

The UV-Vis DR spectra of silicotungstic acid and Fe ${ }^{-G l u S i W}$ are shown in Fig. 3. The spectrum of silicotungstic acid has a wide absorption band in the region $200-450 \mathrm{~nm}$, with peaks at 210 and $265 \mathrm{~nm}$; these are attributed to charge transfer from $\mathrm{O}^{2-}$ to $\mathrm{W}^{6+}$ in the Keggin unit for $\mathrm{W}=\mathrm{O}$ and $\mathrm{W}-\mathrm{O}-\mathrm{W}$ bonds, respectively [30]. It is worth noting that the spectrum of FeШGluSiW shows a clear red shift of the absorption onset compared with that of silicotungstic acid. This may be favorable for photocatalysis because of the relatively narrow HOMOLOMO gap of FeШGluSiW.

The XRD patterns of $\mathrm{H}_{4} \mathrm{SiW}_{12} \mathrm{O}_{40}{ }^{*} \times \mathrm{H}_{2} \mathrm{O}$ and $\mathrm{Fe}{ }^{\varpi} \mathrm{GluSiW}$ are shown in Fig. 4. The XRD pattern of a POM reflects its secondary structure, i.e., the three-dimensional arrangements of the heteropolyanions, cations, and other components. Usually, the primary structure of POM is stable (Fig. 2); however, the secondary structure is variable. As shown in Fig. 4, $\mathrm{H}_{4} \mathrm{SiW}_{12} \mathrm{O}_{40} \times \mathrm{H}_{2} \mathrm{O}$ is highly crystalline, whereas $\mathrm{Fe}^{\varpi} \mathrm{GluSiW}$ is less crystalline and possibly contains an amorphous phase.

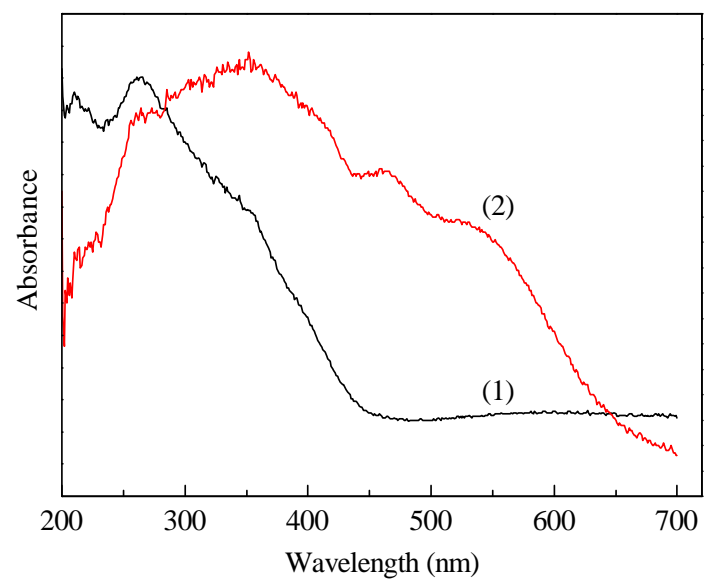

Fig. 3. UV-Vis DRS spectra of (1) silicotungstic acid and (2) FeшGluSiW. 


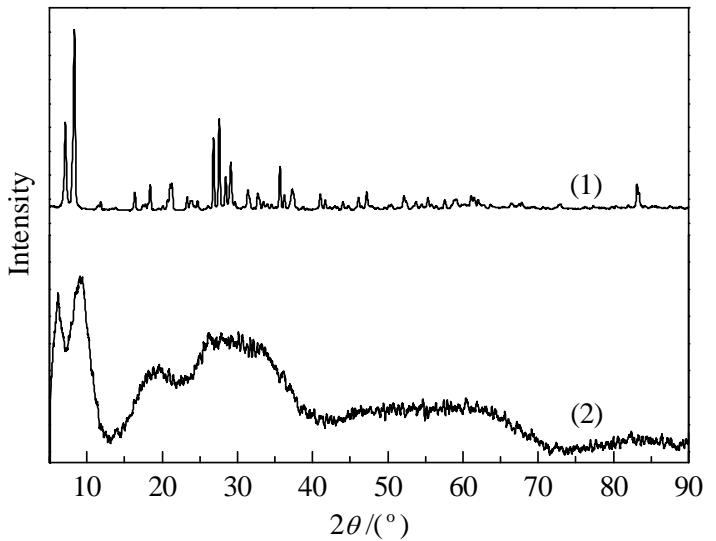

Fig. 4. XRD patterns of (1) silicotungstic acid and (2) Fe ${ }^{\varpi} \mathrm{GluSiW}$.

The SEM image of Fe ${ }^{\amalg}$ GluSiW in Fig. 5 shows irregular particles of size 100-200 nm.

\subsection{Catalytic performance of Fe ${ }^{\amalg} \mathrm{GluSiW}$}

Zero-valent iron (ZVI) has been used as a heterogeneous Fenton-like catalyst for the degradation of 4-CP at ambient temperature [13]. For comparison, the catalytic activity of FeШGluSiW was evaluated under similar conditions: 4-CP 100 $\mathrm{mg} / \mathrm{L}, \mathrm{H}_{2} \mathrm{O}_{2} 20 \mathrm{mmol} / \mathrm{L}$, Fe ${ }^{-} \mathrm{GluSiW} 1.0 \mathrm{~g} / \mathrm{L}$, and temperature $25 \pm 2{ }^{\circ} \mathrm{C}$. The natural starting $\mathrm{pH}$ was 6.5 , and no $\mathrm{pH}$ control was applied throughout the process. All experiments were

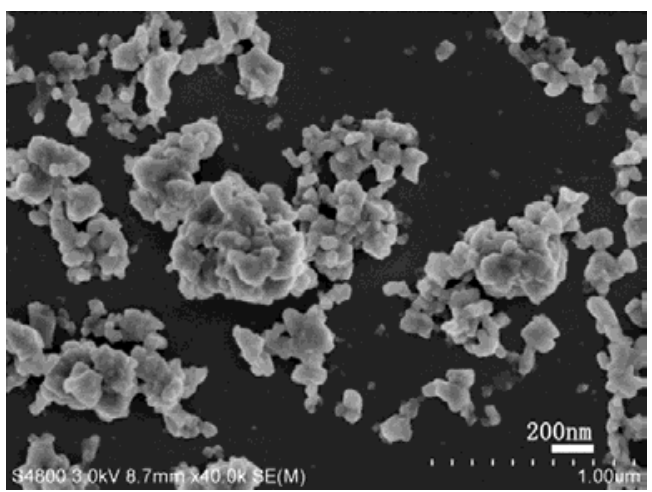

Fig. 5. SEM image of Fe ${ }^{\varpi G l u S i W . ~}$

conducted under dark and irradiated conditions separately.

Control experiments indicated that no significant 4-CP degradation occurred in 40 min when $\mathrm{Fe}{ }^{\varpi} \mathrm{GluSiW}$ or $\mathrm{H}_{2} \mathrm{O}_{2}$ was used alone. However, as shown in Fig. 6, rapid degradation was observed when both $\mathrm{Fe}{ }^{\varpi G l u S i W}$ and $\mathrm{H}_{2} \mathrm{O}_{2}$ were present, and the reaction was significantly accelerated by irradiation. The time required to degrade 4-CP completely was ca. $40 \mathrm{~min}$ in the dark and ca. 15 min under irradiation. Similar to most heterogeneous Fenton-like systems, the reaction rate is also influenced by experimental parameters such as catalyst dosage, $\mathrm{H}_{2} \mathrm{O}_{2}$ concentration, and initial pH value; these issues will be discussed in Section 3.4.

The catalytic performance of $\mathrm{Fe}^{\mathrm{W}} \mathrm{GluSiW}$ at initial $\mathrm{pH}=6.5$ was also evaluated based on TOC removal. The results (Fig. 7)
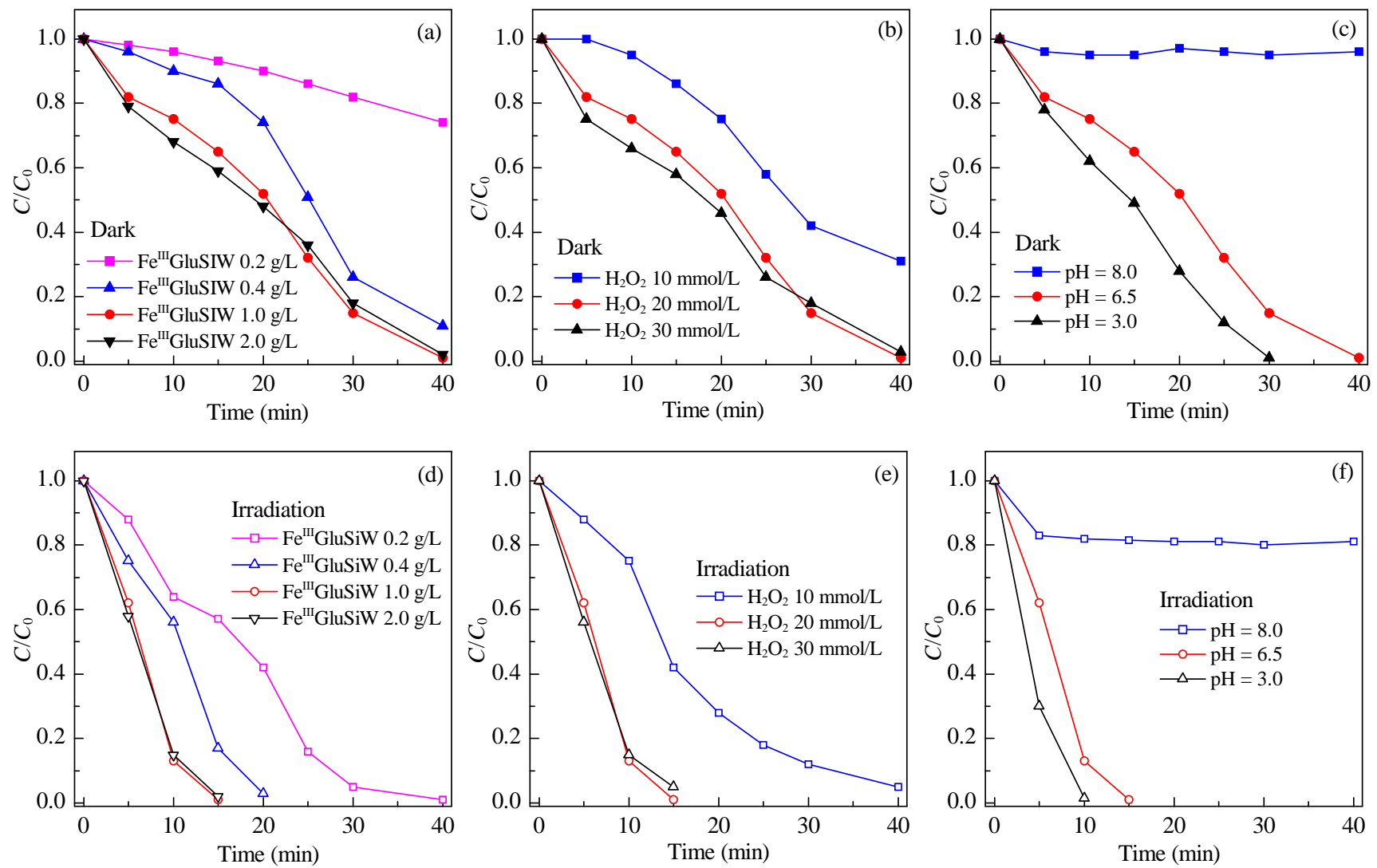

Fig. 6. 4-CP removal in the $\mathrm{Fe}^{\mathrm{II}} \mathrm{GluSiW} / \mathrm{H}_{2} \mathrm{O}_{2}$ system. Except for the investigated parameter, others fixed on $\mathrm{Fe}{ }^{I I I} \mathrm{GluSiW} 1.0 \mathrm{~g} / \mathrm{L}$, $\mathrm{H}_{2} \mathrm{O}_{2} 20 \mathrm{mmol} / \mathrm{L}$, and $\mathrm{pH}=6.5$. 


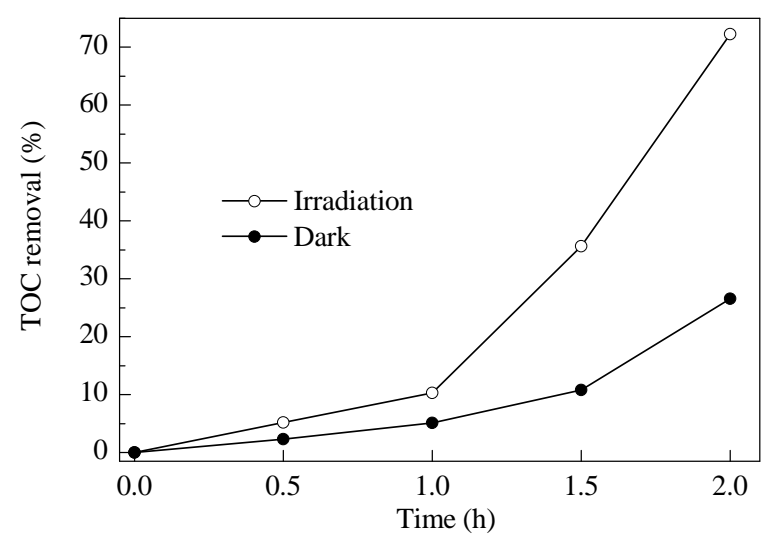

Fig. 7. TOC removal from 4-CP solution in $\mathrm{Fe}$ III GluSiW/ $/ \mathrm{H}_{2} \mathrm{O}_{2}$ system. Reaction conditions: $\mathrm{Fe}{ }^{\varpi} \mathrm{GluSiW} 1.0 \mathrm{~g} / \mathrm{L}, \mathrm{H}_{2} \mathrm{O}_{2} 20 \mathrm{mmol} / \mathrm{L}, \mathrm{pH}=6.5$.

show that TOC removal after $2 \mathrm{~h}$ was $27 \%$ in the dark and $72 \%$ under irradiation. The Fe ${ }^{\varpi G l u S i W}$ ternary complex therefore showed high Fenton-like catalytic activity in the degradation of 4-CP, without any $\mathrm{pH}$ adjustment (at natural $\mathrm{pH}=6.5$ ), and the reaction rate clearly increased under irradiation. In contrast, it has been reported that ZVI has no catalytic activity in 4-CP degradation at $\mathrm{pH}>4.0$ [13].

\subsection{Stability and reusability of Fe ${ }^{W}$ GluSiW}

The stability of a solid heterogeneous catalyst during reactions is crucial to its reusability. In solution, $\mathrm{SiW}_{12} \mathrm{O}_{40^{4-}}$ can be hydrolyzed to $\mathrm{SiO}_{3}{ }^{2-}$ and $\mathrm{WO}_{4}{ }^{2-}$ at neutral or alkaline $\mathrm{pH}$ values [18]. In reaction systems of initial $\mathrm{pH}=6.5, \mathrm{Fe} \mathrm{GGluSiW}$ is therefore expected to be unstable and prone to decomposition through hydrolysis of $\mathrm{SiW}_{12} \mathrm{O}_{40^{4-}}$ in $\mathrm{Fe} \mathrm{WGluSiW}$. Furthermore, the glutamate moiety in FeШGluSiW is possibly oxidized during this procedure, which also results in the decomposition of FeШGluSiW. If FeШGluSiW decomposes during 4-CP degradation, $\mathrm{Fe}, \mathrm{Si}$, and $\mathrm{W}$ at appropriate concentrations should be detected in the bulk solution by ICP-AES. The stability of FeШGluSiW during 4-CP degradation at $\mathrm{pH}=6.5$ was investigated by separating the $\mathrm{Fe}^{\mathrm{W}} \mathrm{GluSiW}$ powder from the solution after the reaction (recovery yield ca. 80\%-90\%). The concentrations of $\mathrm{Fe}, \mathrm{Si}$, and $\mathrm{W}$ in the solution were ca. 0.018, 0.0086, and $0.096 \mathrm{mmol} / \mathrm{L}$, respectively, for the dark system, and ca. $0.030,0.012$, and $0.14 \mathrm{mmol} / \mathrm{L}$, respectively, for the irradiated system. This shows that in addition to the unavoidable loss of

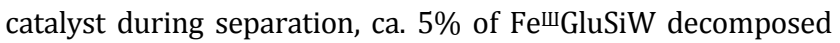
during the reaction. The separated $\mathrm{Fe}^{\mathrm{W}} \mathrm{GluSiW}$ was characterized using FT-IR; the results are shown in Fig. 2 and Table 1. There are no obvious differences between the FT-IR spectra of the freshly prepared Fe ${ }^{-G l u S i W}$ and used Fe ${ }^{-G l u S i W}$ samples. Experiments confirmed that there were no significant differences in the Fe ${ }^{\varpi G l u S i W}$ activity after three cycles for both the dark and irradiated systems. The Fe ${ }^{\amalg} \mathrm{GluSiW}$ catalyst is therefore stable during 4-CP degradation.

$\mathrm{SiW}_{12} \mathrm{O}_{40}{ }^{4-}$ immobilized in water-insoluble $\mathrm{Fe}{ }^{Ш \mathrm{GluSiW}}$ is more resistant to hydrolysis than $\mathrm{SiW}_{12} \mathrm{O}_{40^{4-}}$ dissolved in water. This is similar to the reported observation that $\mathrm{PW}_{12} \mathrm{O}_{40} 0^{3-}$ immobilized in $\mathrm{SiO}_{2}$ matrix is stable in a neutral $\mathrm{pH}$ medium [31]. Also, in contrast to the fast oxidation of 4-CP, oxidation of the glutamate moiety in the $\mathrm{Fe}^{\mathrm{W}} \mathrm{GluSiW}$ catalyst is retarded. The exact reasons for the stabilities of the $\mathrm{SiW}_{12} \mathrm{O}_{40} 0^{4-}$ and glu-

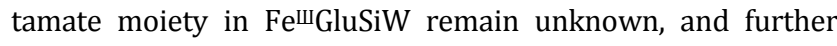
investigation is needed.

\subsection{Possible catalytic mechanism of Fe ${ }^{\amalg}$ GluSiW}

The widely accepted catalytic mechanism in heterogeneous Fenton-like systems using iron-based solid catalysts is similar to that in homogeneous $\mathrm{Fe}^{2+} / \mathrm{H}_{2} \mathrm{O}_{2}$ or $\mathrm{Fe}^{3+} / \mathrm{H}_{2} \mathrm{O}_{2}$ systems; these involve a redox cycle between $\mathrm{Fe}^{3+}$ and $\mathrm{Fe}^{2+}$ ions on the catalyst surface and production of $\mathrm{HO} \cdot$ from $\mathrm{H}_{2} \mathrm{O}_{2}$ decomposition. However, previous studies have indicated the formation of ferryl ( $\mathrm{Fe}^{\mathrm{IV}}$ ) species under some conditions; this is a weaker oxidant than $\mathrm{HO}^{\bullet}$ and cannot oxidize aromatic compounds [32]. It has been suggested that in $\mathrm{POM}$ photocatalysis, $\mathrm{HO} \cdot$ can be formed through $\mathrm{H}_{2} \mathrm{O}$ activation by an excited POM [33].

The oxidative intermediate species formed in the $\mathrm{Fe}{ }^{\mathrm{III}} \mathrm{GluSiW} / \mathrm{H}_{2} \mathrm{O}_{2}$ system were detected by performing control experiments involving addition of $0.3 \mathrm{~mol} / \mathrm{L} n$-butanol (an HO• scavenger) to the reaction system at $\mathrm{pH}=6.5$. The results show that 4-CP degradation was significantly retarded in both the dark and irradiated systems, indicating that $\mathrm{HO}^{\bullet}$ is the dominant oxidative intermediate species in the $\mathrm{Fe}{ }^{\mathrm{III}} \mathrm{GluSiW} / \mathrm{H}_{2} \mathrm{O}_{2}$ system.

Control experiments were performed in two homogeneous mixed solutions, each containing $100 \mathrm{mg} / \mathrm{L}$ of 4-CP, to investigate possible degradation of 4-CP in the bulk solution. One solution contained $0.028 \mathrm{mmol} / \mathrm{L} \mathrm{Fe}^{3+}$ (ferric chloride), 0.014 mmol/ $\mathrm{L} \mathrm{SiO}_{3}{ }^{2-}$ (sodium silicate), and $0.168 \mathrm{mmol} / \mathrm{L} \mathrm{WO}_{4}{ }^{2-}$ (sodium tungstate), and the other contained $0.028 \mathrm{mmol} / \mathrm{L}$ $\mathrm{Fe}^{3+}$ and $0.014 \mathrm{mmol} / \mathrm{L} \mathrm{SiW}_{12} \mathrm{O}_{40^{4-}}$ (silicotungstic acid). The two aqueous solutions are equivalent to the bulk solution phase of the $\mathrm{Fe}{ }^{\amalg G l u S i W} / \mathrm{H}_{2} \mathrm{O}_{2}$ system, on the basis that $5 \%$ of the catalyst decomposes during the reaction, as mentioned in Section 3.3. The former solution corresponds to the case in which FeШGluSiW decomposes through hydrolysis of $\mathrm{SiW}_{12} \mathrm{O}_{40}{ }^{4-}$, and the latter represents decomposition of Fe ${ }^{\varpi G l u S i W}$ through oxidation of glutamate. Both solutions were adjusted to $\mathrm{pH}=6.5$, followed by addition of $\mathrm{H}_{2} \mathrm{O}_{2}$ to a final concentration of $20 \mathrm{mmol} / \mathrm{L}$. The changes in 4-CP concentration were monitored. The results show that 4-CP degradation was negligible under both dark and irradiated conditions. The formation of $\mathrm{HO}^{-}$and degradation of 4-CP in the heterogeneous $\mathrm{Fe}{ }^{\amalg} \mathrm{GluSiW} / \mathrm{H}_{2} \mathrm{O}_{2}$ system therefore probably occur on or near the FeшGluSiW surface.

For a heterogeneous Fenton-like process, the adsorption of $\mathrm{H}_{2} \mathrm{O}_{2}$ on the catalyst surface is crucial to the formation of $\mathrm{HO}$. Tang's group [34] reported that ethylenediaminetetraacetic acid (EDTA) can significantly enhance the catalytic activity of nano- $\mathrm{BiFeO}_{3}$ for oxidative degradation of bisphenol A. The carboxyl and amino groups in EDTA can concentrate $\mathrm{H}_{2} \mathrm{O}_{2}$ within local areas on the catalyst surface by hydrogen bonding with $\mathrm{H}_{2} \mathrm{O}_{2}$; this facilitates $\mathrm{HO}^{-}$formation. In the case of Fe'IIGluSiW, because of the presence of glutamate moieties and 
$\mathrm{SiW}_{12} \mathrm{O}_{40^{4-}}$ heteropolyanions on the catalyst surface, $\mathrm{H}_{2} \mathrm{O}_{2}$ is also prone to adsorption on the surface via hydrogen bonding. This may be an important reason for the high catalytic activity of FelliGluSiW.

We propose a possible mechanism for FeШGluSiW catalysis, based on our experimental results and those reported in the literature. When the reaction is performed in the dark, the catalytic mechanism for $\mathrm{Fe}^{\mathrm{WGluSiW}}$ is similar to those for iron-based materials, in which $\mathrm{H}_{2} \mathrm{O}_{2}$ reacts with iron ions on the catalyst surface (denoted by $\equiv \mathrm{Fe}^{\mathrm{III}}$ and $\equiv \mathrm{Fe}^{\mathrm{II}}$ ), resulting in the formation of $\mathrm{HO} \cdot$ and oxidation of 4-CP (Eqs. (3)-(5)) [13-17]:

$$
\begin{gathered}
\equiv \mathrm{Fe}^{\mathrm{III}}+\mathrm{H}_{2} \mathrm{O}_{2} \stackrel{h v}{\longrightarrow} \equiv \mathrm{Fe}^{\mathrm{II}}+\mathrm{H}^{+}+\mathrm{HO}_{2} \\
\equiv \mathrm{Fe}^{\mathrm{II}}+\mathrm{H}_{2} \mathrm{O}_{2} \rightarrow \equiv \mathrm{Fe}^{\mathrm{III}}+\mathrm{HO}^{-}+\mathrm{HO} \cdot \\
4-\mathrm{CP}+\mathrm{HO} \cdot \rightarrow \text { oxidized products }
\end{gathered}
$$

The hydrogen-bonded $\mathrm{H}_{2} \mathrm{O}_{2}$ on the $\mathrm{Fe}{ }^{\varpi} \mathrm{GluSiW}$ surface is highly reactive with $\mathrm{Fe}^{\mathrm{III}}$ and $\mathrm{Fe}^{\mathrm{II}}$, resulting in fast production of $\mathrm{HO}^{*}$, and therefore rapid degradation of 4-CP.

When the reaction is conducted under irradiation, the reduction of $\equiv \mathrm{Fe}^{\mathrm{III}}$ to $\equiv \mathrm{Fe}^{\mathrm{II}}$ via Eq. (3) is accelerated, resulting in enhanced production of $\mathrm{HO} \cdot$ via Eq. (4) [35]. More importantly, 4-CP is also oxidized through a photocatalytic route mediated by $\mathrm{SiW}_{12} \mathrm{O}_{40}{ }^{4-}$ in $\mathrm{Fe}^{\amalg} \mathrm{GluSiW}$. For POM photocatalysis, the oxidation of organic compounds is suggested to occur via two parallel reaction routes, i.e., oxidation by an excited POM ( $\left.\mathrm{POM}^{*}\right)$ and by $\mathrm{HO} \cdot$ produced via activation of $\mathrm{H}_{2} \mathrm{O}$ by an excited POM [33]. The reduced POM ( $\left.\mathrm{POM}^{-}\right)$is oxidized by $\mathrm{O}_{2}$ to close the catalytic cycle. Photocatalysis by $\mathrm{Fe}^{\mathrm{W}} \mathrm{GluSiW}$ of the degradation of 4-CP is expressed by Eqs. (6)-(8):

$$
\begin{gathered}
\equiv\left[\mathrm{SiW}_{12} \mathrm{O}_{40^{4-}}\right] \stackrel{h v}{\longrightarrow} \equiv\left[\mathrm{SiW}_{12} \mathrm{O}_{40^{4-}}\right]^{*} \\
\equiv\left[\mathrm{SiW}_{12} \mathrm{O}_{40^{4-}}\right]^{*}+4-\mathrm{CP} \rightarrow \equiv\left[\mathrm{SiW}_{12} \mathrm{O}_{40^{5-}}\right]+\text { oxidized product } \\
\equiv\left[\mathrm{SiW}_{12} \mathrm{O}_{40^{4-}}\right]^{*}+\mathrm{H}_{2} \mathrm{O} \rightarrow \equiv\left[\mathrm{SiW}_{12} \mathrm{O}_{40^{5-}}\right]+\mathrm{H}^{+}+\mathrm{HO} \cdot \\
\equiv\left[\mathrm{SiW}_{12} \mathrm{O}_{40^{5-}}\right]+\mathrm{O}_{2} \rightarrow \equiv\left[\mathrm{SiW}_{12} \mathrm{O}_{40^{4-}}\right]+\mathrm{O}_{2} \\
\equiv\left[\mathrm{SiW}_{12} \mathrm{O}_{40^{5-}}\right]+\mathrm{H}_{2} \mathrm{O}_{2}+\mathrm{H}^{+} \rightarrow \equiv\left[\mathrm{SiW}_{12} \mathrm{O}_{40^{4-}}\right]+\mathrm{H}_{2} \mathrm{O}+\mathrm{HO} \bullet
\end{gathered}
$$

We noted that the $\mathrm{Fe}{ }^{\varpi G l u S i W}$ powder changed to dark brown from red-brown during the irradiated reaction. This confirms reduction of $\mathrm{SiW}_{12} \mathrm{O}_{40^{4-}}$ during the reaction. It is worth noting that most POMs by themselves are not good photocatalysts because of slow oxidation of $\mathrm{POM}^{-}$by $\mathrm{O}_{2}$ (Eq. (9)) [18]. This may be why 4-CP degradation under irradiation is slow when $\mathrm{Fe}{ }^{\amalg G l u S i W}$ is used alone without addition of $\mathrm{H}_{2} \mathrm{O}_{2}$. However, in the presence of both $\mathrm{Fe}{ }^{\varpi} \mathrm{GluSiW}$ and $\mathrm{H}_{2} \mathrm{O}_{2}, \mathrm{H}_{2} \mathrm{O}_{2}$ can oxidize $\mathrm{SiW}_{12} \mathrm{O}_{40}{ }^{5-}$ to $\mathrm{SiW}_{12} \mathrm{O}_{40^{4-}}$, producing additional $\mathrm{HO}^{-}$ species (Eq. (10)) [25]. This proposal is supported by the fact that the redox potential of $\mathrm{H}_{2} \mathrm{O}_{2}$ to $\mathrm{HO} \cdot$ and $\mathrm{H}_{2} \mathrm{O}(+0.71 \mathrm{~V}$ versus the normal hydrogen electrode [36]) is more positive than that of $\mathrm{SiW}_{12} \mathrm{O}_{40}{ }^{4-}$ to $\mathrm{SiW}_{12} \mathrm{O}_{40^{5-}}(+0.057 \mathrm{~V}$ versus the normal hydrogen electrode [37]). Additionally, the hydrogen bonding of $\mathrm{H}_{2} \mathrm{O}_{2}$ on the $\mathrm{Fe}{ }^{\varpi G l u S i W}$ surface may promote oxidation of $\mathrm{SiW}_{12} \mathrm{O}_{40} 0^{5-}$ by $\mathrm{H}_{2} \mathrm{O}_{2}$. The photocatalytic activity of $\mathrm{Fe}^{\varpi} \mathrm{GluSiW}$ is therefore enhanced by the presence of $\mathrm{H}_{2} \mathrm{O}_{2}$. In summary, the increased rate of 4-CP degradation under irradiation is ascribed to simultaneous oxidations of 4-CP through Fenton-like and photocatalytic routes mediated by ferric iron and $\mathrm{SiW}_{12} \mathrm{O}_{40}{ }^{4-}$ heteropolyanions, respectively, in $\mathrm{Fe}{ }^{Ш \mathrm{GluSiW}}$.

The proposed catalytic mechanism explains the effects of catalyst dosage, $\mathrm{H}_{2} \mathrm{O}_{2}$ concentration, and initial $\mathrm{pH}$ value. As shown in Fig. 6(a) and (d), 4-CP degradation was hindered by decreasing the catalyst dosage from 1.0 to $0.2 \mathrm{~g} / \mathrm{L}$, and did not change significantly with increasing dosage from 1.0 to $2.0 \mathrm{~g} / \mathrm{L}$. The formation of $\mathrm{HO} \cdot$ and oxidation of 4-CP mainly occur on the catalyst surface. A lower catalyst dosage (e.g., $0.2 \mathrm{~g} / \mathrm{L}$ ) provides fewer active sites; therefore, smaller amounts of $\mathrm{H}_{2} \mathrm{O}_{2}$ and 4-CP are attached to the catalyst surface, resulting in a lower reaction rate. However, addition of an excess of catalyst to the reaction system (e.g., $2.0 \mathrm{~g} / \mathrm{L}$ ) leads to considerable agglomeration of catalyst powder, reducing the increase in the number of active sites caused by increasing the catalyst dosage. When the reaction is carried out under irradiation, the presence of excess catalyst reduces light penetration through water, and this retards the photocatalytic degradation of 4-CP.

Fig. 6(b) and (e) shows that decreasing the $\mathrm{H}_{2} \mathrm{O}_{2}$ concentration from 20 to $10 \mathrm{mmol} / \mathrm{L}$ inhibited the reaction. A lower $\mathrm{H}_{2} \mathrm{O}_{2}$ concentration results in decreased adsorption of $\mathrm{H}_{2} \mathrm{O}_{2}$ on the catalyst surface, leading to reduced production of $\mathrm{HO} \cdot$ via Eqs. (3) and (4), and slower oxidation of $\mathrm{SiW}_{12} \mathrm{O}_{40}{ }^{5-}$ by $\mathrm{H}_{2} \mathrm{O}_{2}$ via Eq. (10). The oxidation of 4-CP through both the Fenton-like and photocatalytic routes is therefore hindered. However, the reaction rate did not increase correspondingly when the concentration of $\mathrm{H}_{2} \mathrm{O}_{2}$ was increased from 20 to $30 \mathrm{mmol} / \mathrm{L}$ because of scavenging of $\mathrm{HO} \cdot$ by excess $\mathrm{H}_{2} \mathrm{O}_{2}[7,13]$. Furthermore, coverage of too many active sites on the catalyst by $\mathrm{H}_{2} \mathrm{O}_{2}$ molecules, i.e., a too high $\mathrm{H}_{2} \mathrm{O}_{2}$ concentration, restrains the adsorption of 4-CP, which is unfavorable for 4-CP oxidation.

The degradation of 4-CP was enhanced by lowering the initial pH from 6.5 to 3.0 , and was significantly retarded by increasing the initial pH to 8.0 (Fig. 6(c) and (f)). This is because of the higher redox potential of $\mathrm{HO} \cdot$ and less decomposition of $\mathrm{H}_{2} \mathrm{O}_{2}$ to $\mathrm{O}_{2}$ and $\mathrm{H}_{2} \mathrm{O}$ at lower $\mathrm{pH}[14,38,39]$. Although a low $\mathrm{pH}$ (e.g., 3.0) favors 4-CP degradation in the $\mathrm{Fe}{ }^{\text {III }} \mathrm{GluSiW} / \mathrm{H}_{2} \mathrm{O}_{2}$ system, the reaction rate at an initial $\mathrm{pH}=6.5$, with no $\mathrm{pH}$ adjustment, is still considerable. Fe ${ }^{\mathrm{III}} \mathrm{GluSiW}$ is therefore a promising heterogeneous Fenton-like catalyst for the treatment of CPs.

\section{Conclusions}

An iron-glutamate-silicotungstate ternary complex, Fe'IIGluSiW, was synthesized from ferric chloride, glutamic acid, and silicotungstic acid. The chemical formula of Fe ${ }^{\text {III GluSiW is }}$ $\left[\mathrm{Fe}\left(\mathrm{C}_{5} \mathrm{H}_{8} \mathrm{NO}_{4}\right)\left(\mathrm{H}_{2} \mathrm{O}\right)\right]_{2} \mathrm{SiW}_{12} \mathrm{O}_{40} \cdot 13 \mathrm{H}_{2} \mathrm{O}$, with glutamate moiety and Keggin-structured $\mathrm{SiW}_{12} \mathrm{O}_{40^{4-}}$ heteropolyanion. The prepared Fe ${ }^{Ш G l u S i W}$ showed high catalytic activity in 4-CP oxidation by $\mathrm{H}_{2} \mathrm{O}_{2}$ at neutral $\mathrm{pH}$ under both dark and irradiated conditions. The high catalytic activity of $\mathrm{Fe}^{\mathrm{W}} \mathrm{GluSiW}$ is related to the formation of hydrogen-bonded $\mathrm{H}_{2} \mathrm{O}_{2}$ on the catalyst surface. The enhanced degradation of 4-CP under irradiation is ascribed to the synergetic effect of Fenton-like and photocatalytic oxidations catalyzed by ferric iron and $\mathrm{SiW}_{12} \mathrm{O}_{40}{ }^{4-}$ heteropolyanions, respectively, in $\mathrm{Fe}{ }^{\amalg} \mathrm{GluSiW}$.

\section{References}

[1] Ahlborg U G, Thunberg T M. Crit Rev Toxicol, 1980, 7: 1

[2] Pera-Titus M, García-Molina V, Baños M A, Giménez J, Esplugas S. Appl Catal B, 2004, 47: 219 


\title{
Graphical Abstract
}

Chin. J. Catal., 2015, 36: 2203-2210 doi: 10.1016/S1872-2067(15)61011-7

Iron-glutamate-silicotungstate ternary complex as highly active heterogeneous Fenton-like catalyst for 4-chlorophenol degradation

Dongju Yin, Lizhong Zhang, Xiufeng Zhao*, Han Chen, Qian Zhai Changji University

The high catalytic activity of the catalyst is due to the hydrogen bonding of $\mathrm{H}_{2} \mathrm{O}_{2}$ on the surface. The enhanced degradation of 4-chlorophenol (4-CP) under irradiation is due to simultaneous oxidation of 4-CP through Fenton-like and photocatalytic processes.

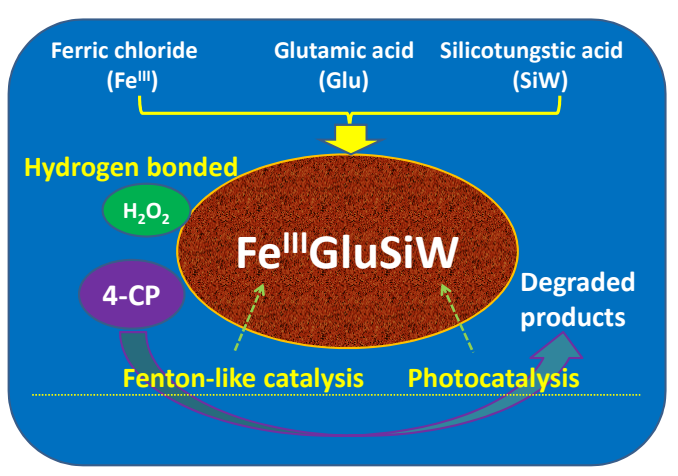

13: 277

[23] Lee J, Kim J, Choi W. Environ Sci Technol, 2007, 41: 3335

[24] Lee C, Sedlak D L.J Mol Catal A, 2009, 311:1

[25] Taghdiri M, Saadatjou N, Zamani N, Farrokhi R. J Hazard Mater, 2013, 246-247: 206

[26] Zhang L Z, Zeng H H, Zeng Y M, Zhang Z H, Zhao X F. J Mol Catal A, 2014, 392: 202

[27] Chen H, Zhang L Z, Zeng H H, Yin D J, Zhai Q, Zhao X F, Li J H. J Mol Catal A, 2015, 406: 72

[28] Jin H X, Wu Q Y, Pang W Q.J Hazard Mater, 2007, 141: 123

[29] López Navarrete J T, Hernández V, Ramírez F J. J Mol Struct, 1995, 348: 249

[30] Jiang C J, Guo Y H, Hu C W, Wang C G, Li D F. Mater Res Bull, 2004, 39: 251

[31] Yue B, Zhou Y, Xu J Y, Wu Z Z, Zhang X, Zou Y F, Jin S L. Environ Sci Technol, 2002, 36: 1325

[32] Keenan C R, Sedlak D L. Environ Sci Technol, 2008, 42: 1262

[33] Guo Y H, Hu C W, Jiang S C, Guo C X, Yang Y, Wang E B. Appl Catal B, 2002, 36: 9

[34] Wang N, Zhu L H, Lei M, She Y B, Cao M J, Tang H Q. ACS Catal, 2011, 1: 1193

[35] Pignatello J J, Liu D, Huston P. Environ Sci Technol, 1999, 33: 1832

[36] Kozhevnikov I V. Chem Rev, 1998, 98: 171

[37] Troupis A, Hiskia A, Papaconstantinou E. Environ Sci Technol, 2002, 36: 5355

[38] Xu L J, Wang J L. J Hazard Mater, 2011, 186: 256

[39] Zhang S X, Zhao X L, Niu H Y, Shi Y L, Cai Y Q, Jiang G B. J Hazard Mater, 2009, 167: 560

\section{铁-谷氨酸-硅铇酸三元配合物作为高活性非均相类Fenton催化剂降解4-氯酚}

\author{
尹冬菊, 张立忠, 赵秀峰*, 陈 汉, 翟 倩 \\ 昌吉学院化学与应用化学系, 新疆昌吉 831100
}

摘要: Fenton氧化法通过 $\mathrm{Fe}^{2+}$ 离子催化分解 $\mathrm{H}_{2} \mathrm{O}_{2}$ 产生羟基自由基, 能够氧化降解绝大多数有机污染物. 但是传统的均相Fenton氧 化法使用高浓度二价铁盐作为催化剂, 催化剂不便于回收利用, 而且还会引发新的环境问题. 另外, 均相Fenton氧化法通常需要在 $\mathrm{pH}$ 约为3 的酸性条件下进行, 在较高 $\mathrm{pH}$ 条件下, 有机物氧化降解速率降低, 同时铁盐水解产生铁泥. 文献报道了一些含铁固体材 料作为非均相类Fenton催化剂, 能够解决催化剂回收和重复利用问题, 但是许多固体催化剂仍然只在酸性条件下表现出较高催化 活性. 多金属氧簇是除过渡金属氧化物之外的一类光催化剂. 近年来, 多金属氧簇在Fenton氧化过程中的应用开始受到关注. 可 以预计, 含铁的多金属氧簇固体化合物有可能同时具有类Fenton催化活性和光催化活性.

本文以三价铁盐 $\left(\mathrm{Fe}^{\mathrm{III}}\right)$ 、谷氨酸 $(\mathrm{Glu})$ 和硅铇酸 $(\mathrm{SiW})$ 为原料在水溶液中合成了一种不溶性的三元固体配合物 $\mathrm{Fe} \mathrm{W}^{\mathrm{WI}} \mathrm{GluSiW}$, 并用 电感耦合等离子体原子发射光谱(ICP-AES)、热重分析(TG)、傅里叶变换红外光谱(FT-IR)、紫外-可见漫反射光谱(UV-Vis DRS)、 
X射线衍射(XRD)和场发射扫描电镜(FE-SEM)对 $\mathrm{Fe}^{\mathrm{W}} \mathrm{GluSiW}$ 进行了表征. 根据ICP-AES, TG和FT-IR结果推断, $\mathrm{Fe} \mathrm{e}^{\mathrm{W}} \mathrm{GluSiW}$ 可能的 化学组成为 $\left[\mathrm{Fe}\left(\mathrm{C}_{5} \mathrm{H}_{8} \mathrm{NO}_{4}\right)\left(\mathrm{H}_{2} \mathrm{O}\right)\right]_{2} \mathrm{SiW}_{12} \mathrm{O}_{40} \cdot 13 \mathrm{H}_{2} \mathrm{O}$, 其中含有铁、谷氨酸根单元和Keggin结构的 $\mathrm{SiW}_{12} \mathrm{O}_{40}{ }^{4}$ 阴离子. FE-SEM和XRD 测试结果表明, $\mathrm{Fe}{ }^{\mathrm{WI}} \mathrm{GluSiW}$ 是由结晶度较低、尺寸为 $100-200 \mathrm{~nm}$ 的无规则颗粒组成, 并含有无定形相.

通过考察在自然初始pH 6.5条件下 $100 \mathrm{mg} / \mathrm{L}$ 4-氯酚(4-CP)在 $\mathrm{Fe}{ }^{\amalg} \mathrm{GluSiW}(1.0 \mathrm{~g} / \mathrm{L}) / \mathrm{H}_{2} \mathrm{O}_{2}(20 \mathrm{mmol} / \mathrm{L})$ 体系中的氧化降解反应, 我 们发现在暗态和光照条件下, 4-CP完全降解所需时间分别为 40 和 $15 \mathrm{~min}$, 延长反应时间至 $2 \mathrm{~h}$, 总有机碳(TOC)去除率分别达到 $27 \%$ 和72\%. 结果表明, $\mathrm{Fe}^{\amalg} \mathrm{GluSiW}$ 具有很高的催化活性, 而且在光照条件下活性更高. 进一步研究发现, Fe ${ }^{\text {W }} \mathrm{GluSiW}$ 在 $\mathrm{pH}$ 3-6.5范围 内均表现出高的催化活性, 而且在酸性条件下活性更高. 用ICP-AES测定Fe元素在溶液中的析出量, 证实4-CP氧化降解主要发生 在固体催化剂表面. 在反应体系中加入正丁醇能显著抑制4-CP降解, 说明4-CP降解反应涉及羟基自由基的氧化作用. 在光照反应 条件下, 催化剂颜色明显变深, 表明光照条件下的反应机理涉及催化剂中 $\mathrm{SiW}_{12} \mathrm{O}_{40}{ }^{4-}$ 阴离子的还原. 考虑到催化剂中含有谷氨酸 根和 $\mathrm{SiW}_{12} \mathrm{O}_{40}{ }^{4}$ 杂多阴离子, 推测 $\mathrm{H}_{2} \mathrm{O}_{2}$ 有可能通过氢键吸附于催化剂表面, 这可能是 $\mathrm{Fe}^{\text {Ш }} \mathrm{GluSiW}$ 表现出高催化活性的重要原因.

结合文献报道的含铁固体材料类Fenton催化机理和多金属氧簇光催化机理,可以很好地解释4-CP降解反应实验结果. 在暗态 条件下, $\mathrm{Fe}^{\mathrm{II}} \mathrm{GluSiW}$ 的催化机理归因于催化剂表面 $\mathrm{Fe} \mathrm{e}^{\mathrm{III}}$ 的氧化还原循环 $\mathrm{Fe}^{\mathrm{III}} \leftrightarrows \mathrm{Fe}^{\mathrm{II}}$, 即 $\mathrm{H}_{2} \mathrm{O}_{2}$ 分子在催化剂表面分解产生羟基自由基, 从而导致4-CP氧化; 而在光照条件下, 除了催化剂中 $\mathrm{Fe}{ }^{\mathrm{III}}$ 的类Fenton催化作用之外, 催化剂中 $\mathrm{SiW}_{12} \mathrm{O}_{40}{ }^{4}$ 杂多阴离子的光催化作用 同时发生, 导致4-CP降解速率加快. 在光催化过程中, 4-CP可以被激发态 $\mathrm{SiW}_{12} \mathrm{O}_{40}{ }^{4-}$ 直接氧化, 也可以被激发态 $\mathrm{SiW}_{12} \mathrm{O}_{40}{ }^{4-}$ 与 $\mathrm{H}_{2} \mathrm{O}$ 相互作用产生的羟基自由基氧化. 被还原的杂多阴离子可以被 $\mathrm{O}_{2}$ 氧化, 也可以被 $\mathrm{H}_{2} \mathrm{O}_{2}$ 氧化, 因而 $\mathrm{H}_{2} \mathrm{O}_{2}$ 的存在也促进了 $\mathrm{Fe}^{\amalg} \mathrm{GluSiW}$ 的光催化作用.

关键词: 多金属氧簇; 硅铇酸; 非均相催化; Fenton氧化; 4-氯酚降解

收稿日期: 2015-08-30. 接受日期: 2015-11-07. 出版日期: 2015-12-20.

*通讯联系人. 电话/传真: (0994)2352065; 电子信箱: zhaoxiufeng19670@126.com

基金来源：国家自然科学基金(51268001).

本文的英文电子版由Elsevier出版社在ScienceDirect上出版(http://www.sciencedirect.com/science/journal/18722067). 